experience, similar illustrations, one of which is worth recording. When residing in the valley of the Ouse, in Bedfordshire, during an occasional absence from home, a well was sunk near my house. The workmen came upon the lower jaw of a hippopotamus, and of course proceeded to demolish it with their pickaxes. A friend of mine happened to pass, and he succeeded in saving for me some fragments of teeth and jaw. When I returned, the bulk of the remains had been used as stuffing to the back of the well. But my friend had saved sufficient to prove the existence of Hippopotamus major in that locality.

This union of effort necessarily involves some amount of friendly rivalry. It seems to be a law of humanity that two vigorous persons, jogging side by side along the same road, stimulate each other to increased pace. And so, in each society, the blending of effort is a stimulus to each individual worker. In a union of societies, the same power should be felt ; each will vie with the others, not simply for pre-eminence of course, but for progress. And the result comes unconsciously in the advancement of the object they have in common. Geologists in the nations of Europe and America, organized in various societies, and surrounded by different influences, have one common object, and mutually stimulate each other towards the attainment of full and complete geological knowledge. It may be, sometimes, that this rivalry will lead to strenuous conflict ; but conflict of opinion and thought, so long as personal rancour and strife are excluded, will always lead onwards in the path of truth.

(2) In approaching the matter of money-whether public or private-devoted to 'geological objects, I touch a subject of some magnitude, complexity, and difficulty. When the British purse is appealed to, buttons are often in requisition, not in liev of coins, but to close the exit of coins. But it is perfectly clear that geological investigation is expensive, and the pecuniary resources of most competent geological observers are limited. Geologists have to rely, for the most part, upon natural sections and exposures, or upon those artificial sections and borings which commercial enterprise opens up. A judicious expenditure of money to make artificial sections and borings, in order to determine crucial points, would often be amply repaid.

In the allocation of public money to geological objects, we have conspicuously before us the Geological Survey of the Kingdom, the maintenance of the Royal School of Mines, and the Natural History Museum at Kensington. Then, during the last year, a grant in aid of provincial Science Colleges has, after much agitation, been wrung from the Treasury; though how much of this will find its way to geological objects is very problematic. Perhaps the most significant "sign of the times" in this direction is the Report of the Committee, appointed by the Commissioners of the $185 \mathrm{I}$ Exhibition, as to the establishment of Science Scholarships in provincial and colonial Universities and Colleges. The second item of the Committee's recommendation runs thus: "That the scholarships be limited to those branches of science (such as physics, mechanics, and chemistry) the extension of which is specially important for our national industries" (NATURE, vol. xlii. p. 43I). Of course this is a case of complete powerlessness on the part of geologists. The Commissioners are acting within their rights, and after due deliberation. But, with all deference to the illustrious men of science who have drawn up this Report, I humbly think that geology ought not to be excluded from the subjects that are specially important for our national industries.

Various scientific Societies allocate money in aid of geological research. The grants from the Royal Society and the British Association have been of great service, not only in rousing activity, but also in rewarding, or rather recompensing, worthy work. The Geological Society of London has at its disposal several most honourable awards for well-spent labour. The medals come first-the Wollaston, Murchison, Bigsby, and Lyell Medals being the highest geological honours of the country. But the surpluses of these funds, as also the "BarlowJameson Fund," are allocated from time to time to repay in some measure the expenses of those who have rendered distinguished service and wrought good work. With us in the Midlands the Darwin Medal of the Midland Union, and the grants made from our " Endowment of Research Fund," are a humble reflex of such awards. There is ample scope for extension and enlargement in awards of this kind.

But perhaps the development of future British geology may come from other sources. The enterprise of the South-Eastern Railway directors has opened up the possibility of coal-fields where thirty-five years ago geologists said they might exist; and public companies can do much to aid further research. Private enterprise also may do much. This old land of ours is not yet used up, and one need not despair of discovering still, in its soil and rocks, fresh elements of permanence and power.

I have thus endeavoured to trace what seem to me to be the possibilities of future geology. There may be regions yet unsearched which will yield up their treasures to the diligent. The current controversies on theoretical points afford scope for the acutest intellect to unravel and explain. New methods of research give promise of coming discoveries. The spirit of the age and the surroundings of the science are favourable on the whole to progress. If money be forthcoming to meet needful expenses, and cbservers are careful and accurate, the past triumphs of geology will appear small compared to the triumphs that are yet to come.

\section{THE SOUTH AFRICAN DOCTRINE OF SOULS.}

$\mathrm{IN}$ the second of two interesting papers on the manners, cus-

toms, superstitions, and religions of South African tribes (Journal of the Anthropological Institute, vol. xix. No. 3, and vol. xx. No. 2), the Rev. James Macdonald, who has had ample opportunities of studying the subject, has a good deal to say about the doctrine of souls which prevails among the aborigines of South Africa. It is extremely difficult, he explains, to discover what the people really believe about the spirit world, so many and varied are the traditions relating to it. There are, however, certain outstanding facts common to all ; and of these Mr. Macdonald gives a clear and instructive account.

All human beings are supposed to have souls, but their souls are not believed to be entirely confined to the body. A man's soul may, it is thought, occupy the roof of his hut, and, if he changes his residence, his soul does so at the same time. Mr. Macdonald takes this to be a loose and indefinite way of expressing "the belief that a man's spirit may have in fluence at a distance from the place where he is himself at any time." The people often use the word "zitunzela"-from "izitunzi," shadows-to express their ideas of human spirits and the unseen world generally ; and this is " the nearest description that can be obtained." A man is constantly attended by the shadows or spirits of his ancestors as well as his own, but the spirit of one who dies without speaking to his children shortly before death never visits his descendants except for purposes of evil. In such cases magicians or priests offer costly sacrifices to prevent misfortune and death.

Great importance is attached to dreams or visions, which are supposed to be due to spirit influence. When the same dream comes more than once, the dreamer consults the magicians, who profess to receive revelations through dreams. If the dreamer has seen "a departed relative," the magician says, " $\mathrm{He}$ is hungry." Then a beast is killed ; the blood is collected, and placed in a vessel at the side of the hut farthest from the door the liver is hung up in the hut, and must not be eaten until al the flesh of the animal has been used. The "essence" of the food is "withdrawn" by the spirit during the night, and after a specified time ail may be eaten except the portions which the magician orders to be burned.

Ancestor-worship is not only professed by the South African tribes, but "they actually regulate their conduct by it." Says Mr. Macdonald :-

"If a man has a narrow escape from accident and death, he says, 'My father's soul saved me,' and he offers a sacrifice of thanksgiving accordingly. In cases of sickness, propitiatory sacrifices are offered to remove the displeasure of the ancestors, and secure a return of their favour. Should anyone neglect a national custom in the conduct of his affairs, he must offer sacrifice to avert calamity as the consequence of his neglect. When offering propitiatory sacrifices, the form of prayer used by the priest is: "Ye who are above, accept our offering and remove our trouble.' In freewill offerings, as in escape from danger, or at the ripening of crops, the prayer takes the following form : 'Ye who are above, accept the food we have provided for you; smell our offering now burning, and grant us prosperity and peace.'"

Animals are not supposed to have souls; neither are inanimate objects. But spirits may reside in inanimate objects, and their presence has an influence on many customs and babits. A striking example of such influence was afforded during the rebellion of 1879 , when Umhlonhlo, after the murder of the British Resident, was one day marching in a leisurely manner 
across country with his whole army. The forenoon was hot, and not a cloud was to be seen. Presently, the magicians noticed on the horizon a peculiarly shaped cloud :- "It rose rapidly in one mass and 'rolled upon itself.' Its movements were intently watched till it approached the zenith and passed over the sun. This was an evil omen. For some unknown cause the spirits were mortally offended, and had come over the army in shadow at noonday. In grief and sorrow their backs were turned upon their children, and the result of this would be certain defeat and disaster. There was, however, no immediate danger. That morning's scouts had reported that there were no troops within many miles of their line of march, and they could repair to some sacred place to offer sacrifices and make atonement. While they were discussing which place to repair to for this purpose, the van of a small column of cavalry appeared unexpectedly over a rising ground. Dismay struck into every heart. The war minister urged his men to form into order of battle. No one answered his summons. He did his best to organize an orderly retreat, but in vain; not a blow was struck, and every man took to his heels, making for the nearest hidingplace in mountain or forest. That army never reassembled. Black-hearted fear utterly demoralized it."

Water or river spirits play a great part in South African mythology. They inhabit deep pools where there are strong eddies and under-currents. They are dwarfs, and are of a malignant disposition, which they display by greedily seizing on anyone who comes within their reach. They are, of course, greatly feared; and the popular dread of them is shown in a way which has been known in many different parts of the world. Mr. Macdonald gives the following example :-

"Some years ago a number of Graleka girls were, on a fine summer day, bathing in the Bashee. One of them got beyond her depth, and began to struggle in the water and cry for help. Her companions promptly raised the alarm, and two men working close by ran down to the water's edge. She was still struggling feebly, but to the onlookers it was a clear case of being 'called' by the river, and they made no attempt to save her. The body was recovered by the magicians the same day, when it was found she had been drowned in less than 5 feet of water. All this came to the ears of C. G. H. Bell, Esq., the English Resident, and he cited the parties, magicians and all, to appear before him in court. The two men not only admitted that they could have waded to the spot where they saw her struggling, but also said the water would not be 'more than breast deep.' They had made no effort to save her, as it would be 'improper and dangerous to interfere when one is called by the river.' Mr. Bell tried to argue them out of such absurd notions, but to little purpose, and finally came to the conclusion that 'six months hard' might be more effectual in eradicating superstition than all his philosophy, and six months hard it accordingly was."

Mr. Macdonald says there is no periodical process of purging or driving away spirits. Without the presence and aid of magicians, ordinary people dare not interfere with these mysterious powers, however malignant and destructive they may become. Although a man is guarded by the spirits of his ancestors, they do not protect him from demons or from wizards and witches. A certain measure of protection can, however, it is supposed, be obtained by the use of charms provided by magicians. On one occasion, when war was being carried on with England, the magicians gave the soldiers a charm against English bullets. It was the blue flower of a species of rhododendron. "Those who carried this talisman rushed forward against columns of infantry without a shadow of fear or hesitation, and only when men began to bite the dust in all directions did the nature of the delusion break upon the army, and panic ensue."

THE ACTION OF LIME ON CLAY SOILS.

THAT lime promotes the fertility of heavy clay soils is a fact that has for many generations been well known to all agriculturists; but the scientific reason for the beneficial action arising from its application has not, to the best of my belief, been at any time at all satisfactorily explained. The question, however, remains one of first importance in the science of soils, and I therefore make no apology for offering an explanation, or rather theory, which, to my doubtless somewhat partial mind, seems to go a considerable way towards the elucidation of the problem.

I take it for granted that all interested know that a clay soil is not by any means a pure clay (hydrated silicate of alumina), but a mixture of impure with pure clay (much more of the former than of the latter), plus sand, iron oxides, organic matter, \&c. The clays which form its bulk have been derived from the natural decay or weathering of mineral silicates, containing, besides, aluminium, alkali, or alkaline-earth metals, and they occur in it in all stages of impurity or further decomposition. As an invariable rule, other things being equal, the greater the normal impurity of the clays the greater the fertility of the soil. A pure piece of clay is like pure quartz-sand-so much dead, inert matter; a plant can make nothing of it, can take nothing from it. In no fertile clay soil, however, even of the heaviest description, does there occur at any time more than about ro per cent. of absolutely pure clay. Well, then, what is the composition of the average clay particle? That depends on the mineral from which it was derived. If from the felspars, its most common origin, it will be a hydrated silicate of alumina plus silicate of potash, or, instead of the potash, soda and lime. I will suppose, for brevity's sake, that my clay particles have the former composition, and the explanation which I will offer with regard to their behaviour can be applied with very little difficulty to any of the other cases. Clay particles of the above com. position, when subjected to the action of water containing carbonic acid gas, lose potash. That I have repeatedly proved by experiment. If the carbonic acid is in fair excess, it comes away altogether as carbonate of potash; but if there is not a sufficiency of this anhydride, it is liberated partly as soluble silicate of potash (soluble glass). Should lime, however, in this latter case be present, the practically insoluble calcium silicate will be constituted, and the potash freed to form a soluble salt with any other acid that may be present and available, such as carbonic, sulphuric, nitric, \&c. A grass plant growing in clay soil does not, it is evident, send sufficient carbonic acid through its root-hairs into the soil, as many other plants do, to completely convert the liberated potash into carbonate, and the consequence is that the soluble silicate of potash which is permitted to form is drawn into the vegetable, as well as the carbonate of that alkali. Now silica and silicates are decidedly injurious, to all vegetables doubtless, but particularly to agricultural plants. I say injurious; the day has gone by for considering silica an essential, or useful, or even a merely innoxious accessory. A little examination of the plant-physiology shows that it is injurious. The organism tries to get rid of it as speedily as possible- that is, at least to get it out of the way of its general circulation; it unfortunately has no means of casting it off altogether. Here, I need scarcely refer to the well-known experiments which have, over and over again, conclusively shown that the grass plant does not require silica as a supporting or strengthening material. Now we come to see the use of lime in the clay soil, especially in the case of the cultivation of cereals and pastural grasses. The lime added and mixed up with the soil acts on the soluble silicate of potash as it is formed, and combines with the silica, constituting, as I have already remarked, the practically insoluble silicate of lime, which, of course, being normally indissolvable in the soil, cannot pass into the body of the plant. Therefore, the organism profits by its exclusion, and as a consequence so does the farmer. The energies of the plant are not spent in getting rid of silica if there is no silica to get rid of, and its ordinary processes of nutrition can progress uninterruptedly.

The breaking up of the soluble silicate ${ }^{1}$ could be as well accomplished by the perfect aëration of the soil so that every particle could be constantly exposed to fresh portions of aërial carbonic acid and oxygen; and this is one great reason why fine deep tillage, where it is possible, so improves clayey soils, but of course a tillage that will bring about the perfect aëration of heavy clay, is all but impossible; therefore the advantage of judiciously using lime.

The soluble alkaline silicate which, when undecomposed, passes into the plant in the water-stream through the roots, is evidently very soon split up by the vegetable, and the silica combined with some substance, such as an aldehyde, and carried on in solution in this state to the peripheries of the stem, \&c., where, by the process of practically unrestrained evaporation, the compound is again split up, the aldehyde going off into the air, and the solid silica remaining stranded in the cuticle and the other walls, or occasionally even in the cavities of the epidermal layer.

$r$ Only the alkali metals, of which potassium and sodium are the only two that normally occur in soils, form silicates soluble in water.

NO. I I O 9, VOL. 43] 